\title{
Pengaruh Model Pembelajaran Reflektif dengan Pendekatan Matematika Realistik Bernuansa Keislaman terhadap Kemampuan Komunikasi Matematis
}

\author{
Fredi Ganda Putra \\ IAIN Raden Intan Lampung: fredigpsw@gmail.com
}

\begin{abstract}
The purpose of this study was to determine the effect of the learning model on students' mathematical communication. The learning model that is compared is a reflective learning model with realistic Islamic nuances and direct learning models. The type of research is comparative causal research. The sampling technique with simple random sampling technique. Data collection techniques with documentation, questionnaires and tests. The population is all seventh grade students at MTs Al-Khairiyah Natar in the 2015/2016 school year. The sample size is 44 students consisting of 22 students in grade 1 and 22 in the control class 1 . The instrument used is a mathematical communication test on quadrilateral learning material. Data were analyzed using t-test. The conclusion of this study is that there is an effect of reflective learning models with realistic mathematical approaches nuanced in Islam resulting in better mathematical communication skills than direct learning models.
\end{abstract}

Keywords: Reflective; Realistic Mathematical Approach; Mathematical Communication.

\begin{abstract}
Abstrak
Tujuan dari penelitian ini adalah untuk mengetahui pengaruh model pembelajaran terhadap komunikasi matematis siswa. Model pembelajaran yang dibandingkan adalah model pembelajaran reflektif dengan pendekatan matematika realistik bernuansa Islam dan model pembelajaran langsung. Jenis penelitiannya adalah penelitian kausal komparatif. Teknik pengambilan sampel dengan teknik simple random sampling. Teknik pengumpulan data dengan dokumentasi, angket dan tes. Populasinya adalah semua siswa kelas VII di MTs AlKhairiyah Natar pada tahun ajaran 2015/2016. Ukuran sampel adalah 44 siswa yang terdiri dari 22 siswa kelas 1 dan 22 di kelas kontrol 1.Instrumen yang digunakan adalah tes komunikasi matematika pada materi pembelajaran segiempat. Data dianalisis dengan menggunakan uji-t. Kesimpulan dari penelitian ini adalah ada pengaruh model pembelajaran reflektif dengan pendekatan matematika realistik bernuansa Islam menghasilkan kemampuan komunikasi matematis yang lebih baik daripada model pembelajaran langsung. Kata Kunci: Reflektif; Pendekatan Matematika Realistik; Komunikasi Matematis.
\end{abstract}

\section{PENDAHULUAN}

Pendidikan diwujudkan dengan proses pembelajaran yang mengusahakan siswa aktif mengembangkan diri agar memiliki pengetahuan dapat mengubah sikap dan tingkah laku menjadi terpelajar serta meningkatkan daya saing globalisasi (Juwita, Gunowibowo, \& Nurhanurawati, 2014). Salah satu faktor yang mempengaruhi berhasil atau tidaknya suatu proses pendidikan adalah proses pembelajaran yang berlangsung di kelas. 
Pembelajaran yang dilakukan di Sekolah bertujuan untuk memperoleh ilmu pengetahuan yang nantinya dibutuhkan oleh peserta didik. Dalam Al-Qur'an surat al mujadilah : 11, Allah berfirman: "...Allah akan meninggikan orang-orang yang beriman diantaramu dan orang-orang yang diberi ilmu pengetahuan beberapa beberapa derajat..." Hal ini menunjukkan bahwa betapa pentingnya mencari ilmu pengetahuan, dan ilmu pengetahuan dapat diperoleh dari proses pembelajaran dikelas. Setiap manusia sejak zaman Nabi Adam juga sudah melakukan proses pembelajaran dari Allah tentang suatu ilmu, hal ini tertuang pada Al Qur'an surah Al Isra ayat 70 yang artinya: Dan Allah mengajarkan kepada Adam nama-nama (benda-benda) seluruhnya, kemudian mengemukakannya kepada para Malaikat lalu berfirman: "Sebutkanlah kepada-Ku nama benda-benda itu jika kamu memang orang-orang yang benar!"

Setiap manusia memiliki karakteristik yang berbeda begitu pun siswa. Keberagaman pribadi tersebut dapat terlihat dari keterampilan siswa yang melibatkan pemikiran kritis, sistematis, logis, kreatif, dan kemampuan bekerja sama yang efektif dalam pembelajaran khususnya pembelajaran matematika (Merry, Sutiarso, \& Nurhanurawati, 2013).

Matematika merupakan salah satu mata pelajaran yang diajarkan diberbagai jenjang pendidikan dimulai dari taman kanak-kanak hingga perguruan tinggi, disebabkan karena pentingnya matematika untuk dapat menyelesaikan masalah di kehidupan sehari-hari. Hal ini dapat diketahui melalui setiap kegiatan manusia yang sering sekali terkait dengan matematika seperti proses jual beli, proses pembangunan gedung, dll. Permendiknas Nomor 20 tahun 2006 menyatakan bahwa pembelajaran matematika bertujuan agar peserta didik memiliki kemampuan sebagai berikut (Wijaya, 2012):

1. Memahami konsep matematika, menjelaskan keterkaitan antar konsep dan mengaplikasikan konsep atau algoritma, secara luwes, akurat, efisien, dan tepat, dalam pemecahan masalah.

2. Menggunakan penalaran pada pola dan sifat, melakukan manipulasi matematika dalam membuat generalisasi, menyusun bukti, atau menjelaskan gagasan dan pernyataan matematika.

3. Memecahkan masalah yang meliputi kemampuan memahami masalah, merancang model matematika, menyelesaikan model menafsirkan solusi yang diperoleh.

4. Mengkomunikasikan gagasan dengan simbol, tabel, diagram, atau media lain untuk memperjelas keadaan atau masalah.

5. Memiliki sifat menghargai kegunaan matematika dalam kehidupan, yaitu memiliki rasa ingin tahu, perhatian, dan minat dalam mempelajari matematika, serta sikap ulet dan percaya diri dalam pemecahan masalah.

Salah satu tujuan pembelajaran matematika menurut Permendiknas Nomor 20 Tahun 2006 ialah mengkomunikasikan gagasan dengan simbol, tabel, diagram, atau media lain untuk memperjelas keadaan atau masalah. Dalam pembelajaran matematika, komunikasi 
matematis baik secara lisan maupun tertulis merupakan hal yang sangat penting di samping penalaran, pembuktian, representasi matematis, dan pemecahanan masalah matematis (Yovita, Bambang, \& Halini, 2013).

Menurut (Umar, 2012), kemampuan komunikasi matematis siswa adalah bagaimana siswa mengomunikasikan ide-idenya dalam usaha memecahkan masalah yang diberikan guru, berpartisipasi aktif dalam diskusi, dan mempertanggungjawabkan jawaban mereka terhadap masalah. Banyak cara yang digunakan untuk meningkatkan komunikasi matematis siswa seperti yang dilakukan oleh (Majidah Khairani, 2015) menggunakan pendekatan metakognitif, (Merry et al., 2013) menggunakan problem posing, (Karimah, 2013) menggunakan model Cooperative Integrated Reading And Composition (CIRC), (Fajri, Hajidin, \& Ikhsan, 2013) menggunakan model Contextual Teaching And Learning (CTL), (Jamilah, Riyadi, \& Roswitha, 2013) menggunakan PMR dengan Discovery Learning, dan (Hutapea, 2014) melalui pembelajaran generatif. Akan tetapi, masih ada kemampuan komunikasi matematis peserta didik yang tergolong rendah hal ini sejalan dengan pendapat (Rahmawati, 2013) yang menyatakan bahwa kemampuan komunikasi matematis peserta didik masih rendah. Kondisi yang serupa terjadi di MTs Al-Khairiyah Natar,hal ini dapat dilihat berdasarkan analisis yang penulis lakukan terhadap hasil ulangan harian peserta didik di sekolah tersebut. Penulis memperoleh kesimpulan bahwa kemampuan peserta didik dalam melukiskan gambar secara lengkap dan benar serta kemampuan memodelkan permasalahan secara benar kemudian melakukan perhitungan secara lengkap dan benar masih tergolong rendah, kelemahan-kelemahan tersebut mengindikasikan bahwa kemampuan komunikasi peserta didik di sekolah MTs Al-Khairiyah masih rendah.

Rendahnya kemampuan komunikasi matematis peserta didik di MTs Al-Khairiyah diduga disebabkan karena model pembelajaran yang guru gunakan di kelas. Guru matematika di Sekolah tersebut masih menggunakan model pembelajaran konvensional, hal ini berdasarkan hasil prasurvey yang telah dilakukan oleh peneliti pada tanggal 12 Januari 2016. Atas hasil prasurvey tersebut, peneliti bermaksud untuk menerapkan suatu tindakan alternatif untuk mengatasi masalah yang ada, yakni dengan penerapan model pembelajaran yang lebih mengutamakan keaktifan peserta didik dan memberi kesempatan peserta didik untuk mengembangkan potensinya secara maksimal. Salah satu model yang dapat digunakan adalah model pembelajaran reflektif.

Model pembelajaran reflektif merupakan pembelajaran dengan melibatkan kegiatan berfikir reflektif pada prosesnya. Refleksi merupakan kegiatan intelektual dan afektif yang melibatkan siswa dalam upaya mengekplorasi pengalaman mereka untuk mencapai pemahaman dan apresiasi-apresiasi baru (Rohana \& Ningsih, 2016). Model pembelajaran ini telah banyak digunakan dalam penelitian sebelumnya yaitu oleh (Aprilia, 2016), (Rohana \& Ningsih, 2016), dan (Prasetyo, Santosa, \& Marjono, 2014). Akan tetapi, penelitian yang dilakukan oleh (Lailiyah, Munzil, \& Suryadharma, 2013) memberikan hasil bahwa penerapan 
model pembelajaran reflektif tidak memberikan pengaruh yang signifikan terhadap hasil belajar peserta didik. Oleh karena itu, peneliti berencana menambahkan pendekatan matematika realistik pada model tersebut.

Menurut Daitin Tarigan dalam (Jumiati, N, \& Zulkifli, 2014), pendekatan matematika realistik adalah pendekatan yang orientasinya menuju kepada penalaran siswa yang bersifat realistik dan ditujukan kepada pengembangan pola pikir praktis, logis, kritis dan jujur dengan berorientasi pada penalaran matematika dalam menyelesaikan masalah. Penggunaan pendekatan ini juga karena penelitian yang dilakukan oleh Septika yang memberikan hasil bahwa pendekatan matematika realistik dapat meningkatkan hasil belajar matematika peserta didik (Septika, 2012).

Nuansa keislaman di dalam pembelajaran di kelas diharapkan dapat membantu peserta didik dalam meningkatkan kemampuan komunikasi matematis peserta didik. Pembelajaran matematika dengan menggunakan pendekatan realistik bernuansa keislaman merupakan nilai tambah yang akan menjadikan peserta didik memahami matematika dan mendapatkan nilai keislaman dalam pembelajarannya, karena nilai keislaman akan disisipkan melalui pendekatan realistik. Sehingga peserta didik diharapkan akan mempunyai kemampuan komunikasi matematis yang baik dan nilai keislaman sebagai nilai tambahnya. Berdasarkan pemaparan dan deskripsi permasalahan yang telah dikemukakan di atas, maka judul penelitian ini tentang Pengaruh Model Pembelajaran Reflektif dengan Pendekatan Matematika Realistik Bernuansa Keislaman terhadap Kemampuan Komunikasi Matematis.

\section{METODE PENELITIAN}

Penelitian ini merupakan penelitian kausal komparatif. Populasi dalam penelitian ini adalah seluruh peserta didik kelas VII MTs Al-Khairiyah Natar dan sampel diambil dengan teknik simple random sampling. Penelitian dilakukan di MTs Al-Khairiyah Natar yang masingmasing diambil kelas VII B sebagai kelas eksperimen dan kelas VII C sebagai kelas kontrol. Sampel penelitian ini berjumlah peserta didik yang terdiri dari 44 peserta didik. Teknik pengumpulan data adalah metode dokumentasi, metode angket, dan metode tes. Instrumen penelitian terdiri atas tes komunikasi matematis pada materi Bangun ruang sisi datar. Uji coba instrumen tes komunikasi matematis dilakukan di kelas VIIA dengan responden 22 peserta didik. Berikutnya untuk Uji analisis data yang digunakan dalam penelitian ini yaitu uji-t.

\section{HASIL PENELITIAN DAN PEMBAHASAN}

Sesuai dengan rancangan penelitian yang telah dirumuskan sebelumnya, uji hipotesis untuk penelitian ini menggunakan uji-t. Uji-t ini dilakukan setelah dipenuhinya persyaratan normalitas populasi dan homogenitas variansi populasi. Dari hasil perhitungan, diperoleh bahwa masing-masing kelompok memiliki data yang normal dan kedua kelompok sampel 


\section{$\mathbf{a} \int \rho \mu$}

Al-Jabar: Jurnal Pendidikan Matematika

Vol. 7, No. 2, 2016, Hal 203 - 210

memiliki varians yang homogen. Karena data telah normal dan homogenya maka langkah selanjutnya adalah melakukan uji-T pada data tersebut. Berikut hasil uji-T menggunakan SPSS 16:

Tabel1.Uji-T menggunakan SPSS

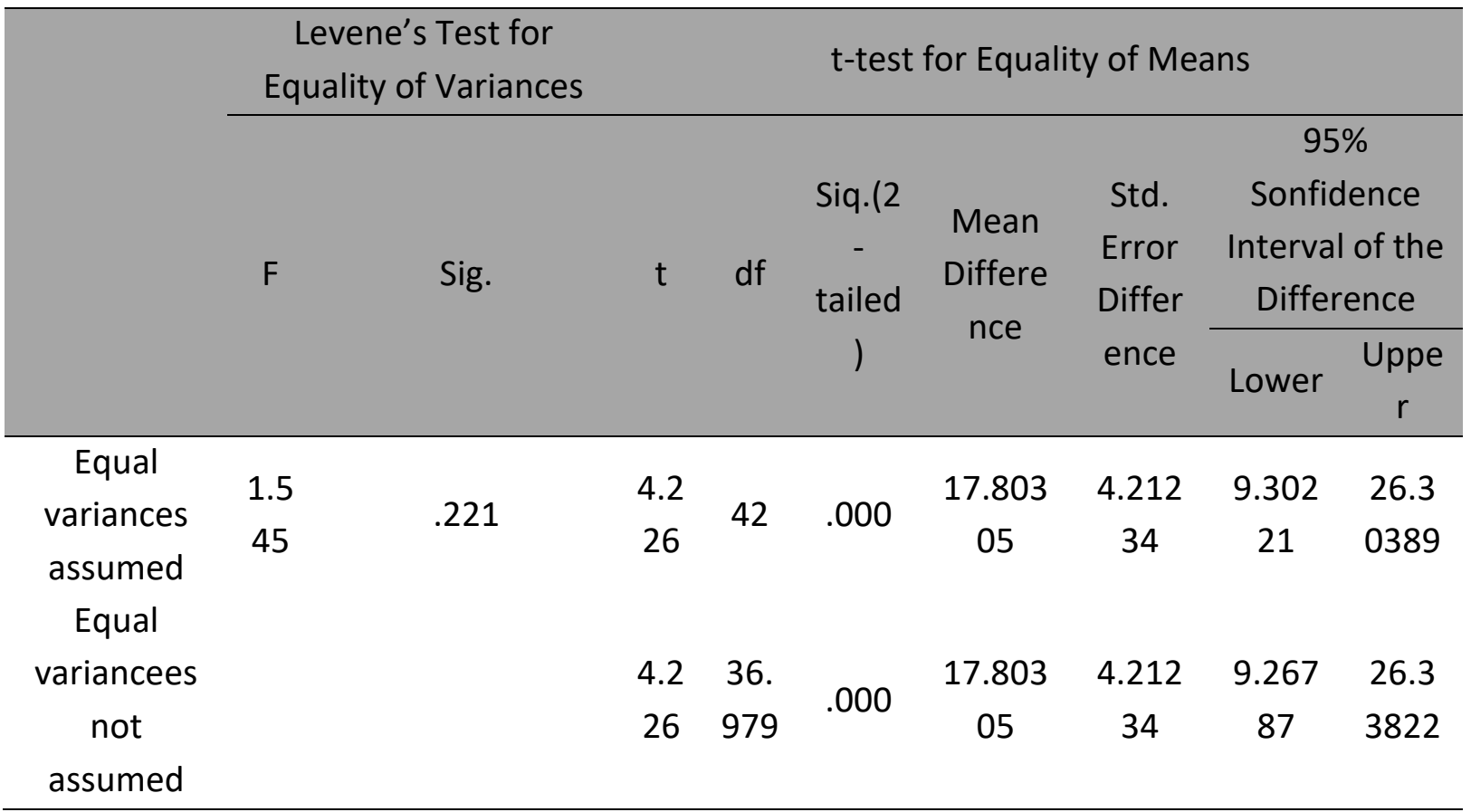

Dari hasil perhitungan menggunakan SPSS diatas, dapat dilihat bahwa nilai Sig.(2tailed) sebesar 0,000 yang mana nilai tersebut lebih kecil dari 0,050 sehingga hal ini dapat dikatakan bahwa terdapat perbedaan antara penerapan pengaruh yang berbeda antar masing-masing kategori model pembelajaran terhadap kemampuan komunikasi matematis, sehingga terdapat perbedaan kemampuan komunikasi matematis antara peserta didik yang mendapat model pembelajaran reflektif dengan pendekatan realistik bernuansa keislaman dan peserta didik yang menggunakan pembelajaran konvensional.

Hasil penelitian ini juga sesuai dengan penelitian Rahmawati yang memberikan hasil bahwa model pembelajaran reflektif dengan pendekatan realistik bernuansa keislaman memberikan kemampuan komunikasi matematis lebih baik dari model pembelajaran konvensional (Rahmawati, 2013)

Melihat lebih jauh mengenai Pembelajaran reflektif dengan pendekatan realistik bernuansa keislaman akan memberikan pengalaman kepada peserta didik dengan mengaitkan kehidupan sehari-hari yang bernilai islami kedalam matematika sehingga membentuk pemahaman yang baru. Pembelajaran ini menekankan pada kegiatan intelektual dan afektif dimana peserta didik terlibat dalam upaya mengeksplorasi pengalaman mereka dalam rangka mencapai pemahaman dan apresiasi-apresiasi baru dalam pembelajaran matematika. Penerapan model pembelajaran reflektif dengan 
pendekatan realistik dalam pembelajaran matematika akan mendorong peserta didik berani mengutarakan pendapat pada proses pembelajaran, selain itu peserta didik tidak hanya memahami pelajaran semata akan tetapi peserta didik akan menemukan pengalaman baru dengan mengaitkan matematika dalam kehidupan sehari-hari sehingga peserta didik tidak kesulitan dalam memahami matematika. Pembelajaran matematika dengan menggunakan pendekatan realistik bernuansa keislaman merupakan nilai tambah yang akan menjadikan peserta didik memahami matematika dan mendapatkan nilai keislaman dalam pembelajarannya karena nilai keislaman akan disisipkan melalui pendekatan realistik sehingga dapat meningkatkan kemampuan komunikasi matematis serta hasil belajar peserta didik menjadi baik.

Secara umum dari kajian pelaksanaan pembelajaran dengan pendekatan realistik menunjukkan bahwa siswa mudah beradaptasi dengan perubahan pendekatan pembelajaran yakni dari pendekatan mekanistik yang selama ini dialami ke pendekatan realistik. Siswa pada pembelajaraan ini cenderung memiliki sikap positip, berani mengemukakan pendapat atau berargumentasi dalam berdiskusi, mandiri dan cepat dalam bekerja, serta memiliki keberanian untuk mencoba cara-cara (ide-ide) baru dalam menyelesaikan soal cerita matematika yang dihadapkan. Ada juga siswa yang cenderung memerlukan dorongan serta perhatian untuk bersedia mengemukakan pendapat dalam berdiskusi, bantuan atau bimbingan dalam bekerja, dan kurang berani untuk mencoba caracara lain dalam menyelesaikan soal cerita matematika, meskipun secara lambat terdapat peningkatan keberanian dalam mengemukakan pendapat.

Meskipun peneliti berusaha untuk mengeliminir kelemahan yang mungkin muncul dalam penelitian ini tetapi akibat dari keterbatasan yang ada pada peneliti ditemukan kemungkinan kelemahan penelitian ini bahwa hal tersebut berakibat pelaksanaan pembelajaran dengan pendekatan realistik (pada kelas eksperimen) dilakukan oleh peneliti dan guru kelas bertindak sebagai pendamping. Sebagai usaha agar manfaat penelitian ini tercapai, setelah pelaksanaan eksperimen dilakukan refleksi dan diskusi dengan guru dan kepala sekolah tempat eksperimen.

\section{SIMPULAN DAN SARAN}

Berdasarkan analisis data dan pengujian hipotesis yang telah dilakukan, maka dapat disimpulkan bahwa terdapat pengaruh yang berbeda pada kemampuan komunikasi matematis peserta didik yang menggunakan pembelajaran reflektif dengan pendekatan realistik bernuansa keislaman dan peserta didik yang menggunakan pembelajaran konvensional.Jika dilihat dari rata-rata marginal masing-masing kelompok dapat disimpulkan bahwa penerapan model pembelajaran reflektif dengan pendekatan matematika realistic bernuansa islami memberikan kemampuan komunikasi matematis yang lebih baik dibandingkan penerapan model pembelajaran konvensional. 
Berdasarkan pelaksanaan dan kesimpulan dari hasil penelitian, ada beberapa hal yang perlu peneliti sarankan yaitu sebagai berikut:

1. Pilihan penggunaan cara penyampaian materi matematika perlu adanya pertimbangan faktor tertentu dalam mendukung pembelajaran, karena tidak semua cara cocok diterapkan pada semua materi belajar.

2. Pembelajaran dengan menggunakan model pembelajaran reflektif dengan pendekatan realistik bernuansa keislaman dapat digunakan sebagai alternatif untuk membuat peserta didik aktif saat proses pembelajaran jika diterapkan secara tepat, namun perlu diketahui tidak semua materi bisa diterapkan dengan pendekatan yang digunakan dalam pembelajaran ini. materi yang yang bisa diterapkan diantaranya materi bangun ruang dan bangun datar.

3. Dibutuhkan keaktifan dan kenyamanan peserta didik dalam belajar matematika untuk mencapai keberhasilan dalam belajar.

4. Pembelajaran dengan menggunakan model pembelajaran reflektif dengan pendekatan realistik bernuansa keislaman sangat cocok diterapkan untuk mengembangkan kemampuan komunikasi peserta didik, karena pembelajaran ini menuntut peserta didik untuk aktif, aktif saat konstruksi ilmu pengetahuan.

\section{DAFTAR PUSTAKA}

Aprilia, N. (2016). Implementasi Model Pembelajaran Reflektif untuk Meningkatkan Kemampuan Pemahaman Mahasiswa Pendidikan Biologi pada Mata Kuliah Strategi Pembelajaran di Program Studi FKIP Universitas Ahmad Dahlan. Jurnal Bioedukatika, 4(1), 27.

Fajri, N., Hajidin, \& Ikhsan, M. (2013). Peningkatan Kemampuan Koneksi Dan Komunikasi Matematis Siswa Dengan Menggunakan Pendekatan Contextual Teaching And Learning (CTL). Paradikma Jurnal Pendidikan, 6(2), 149-161.

Hutapea, N. M. (2014). Pencapaian Kemampuan Komunikasi Matematis Siswa SMA Melalui Pembelajaran Generatif. Jurnal Pendidikan, 4(2), 108-114.

Jamilah, Riyadi, \& Roswitha, M. (2013). Eksperimentasi Pendekatan Pendidikan Matematika Realistik (PMR) Dengan Metode Discovery Learning Pada Materi Pokok Bentuk Aljabar Ditinjau Dari Kemampuan Komunikasi Matematis. Jurnal Pembelajaran Matematika, 1(1), 81-91.

Jumiati, N, L., \& Zulkifli. (2014). Penerapan Pendekatan Pembelajaran Matematika Realistik ( PMR ) Untuk Meningkatkan Hasil Belajar Matematika Siswa Kelas IV SDN 029 Sungai Agas Kecamatan Kubu. Jurnal Online Mahasiswa (JOM) Bidang Keguruan Dan IImu Pendidikan, 1(2), 1-12.

Juwita, J. N., Gunowibowo, P., \& Nurhanurawati. (2014). Pengaruh Model Pembelajaran 


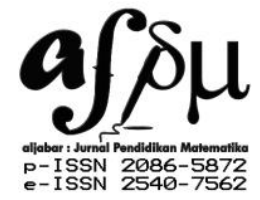

Al-Jabar: Jurnal Pendidikan Matematika

Vol. 7, No. 2, 2016, Hal 203 - 210

Kooperatif Tipe Think Pair Share Terhadap Kemampuan Komunikasi Matematis. Jurnal Pendidikan Matematika Unila, 2(1), 42-49.

Karimah, S. (2013). Pembelajaran Matematika Model Cooperative Integrated Reading And Composition (CIRC) Untuk Meningkatkan Kemampuan Komunikasi Matematis Materi Segiempat Kelas VII. Delta, 1(2), 136-143.

Lailiyah, I., Munzil, \& Suryadharma, I. B. (2013). Pengaruh Penerapan Model Pembelajaran Reflektif Sifat Elektrolit-Non Elektrolit Terhadap Hasil Belajar Siswa Kelas X Man Malang 1. SKRIPSI Jurusan Kimia-Fakultas MIPA UM, 1-8.

Majidah Khairani. (2015). Pendekatan Metakognitif Untuk Meningkatkan Kemampuan Komunikasi Matematis Siswa Kelas X SMAN 3 Payakumbuh. Jurnal Ipteks Terapan, 9(4), 253-260.

Merry, R., Sutiarso, S., \& Nurhanurawati. (2013). Pengaruh Pendekatan Problem Posing Terhadap Kemampuan Komunikasi Matematis Siswa. Jurnal Pendidikan Matematika Unila, 1(7), 1-10. https://doi.org/10.14042/j.cnki.32.1309.2013.06.005

Prasetyo, A., Santosa, S., \& Marjono. (2014). Penerapan Model Pembelajaran Reflektif Pada Pembelajaran Biologi Terhadap Hasil Belajar Siswa Kelas X SMA Negeri Colomadu Tahun Pelajaran 2012/2013. Bio-Pedagogi, 3(1), 1-10.

Rahmawati, F. (2013). Pengaruh Pendekatan Pendidikan Realistik Matematika dalam Meningkatkan Kemampuan Komunikasi Matematis Siswa Sekolah Dasar. Prosiding SEMIRATA 2013, 1(1), 225-238. RRohana, \& Ningsih, Y. L. (2016). Model Pembelajaran Reflektif Untuk Meningkatkan Kemampuan Pemecahan Masalah Matematis Mahasiswa Calon Guru. JPPM, 9(2), 145-158.

Septika, L. C. (2012). Pendidikan Matematika Realistik Terhadap Hasil Belajar Penjumlahan Pecahan Anak Tunanetra. Jurnal Pendidikan Khusus.

Umar, W. (2012). Membangun Kemampuan Komunikasi Matematis Dalam Pembelajaran Matematika. Infinity Journal, 1(1), 1.

Wijaya, A. (2012). Pendekatan Matematika Realistik: Suatu Alternatif Pendekatan Pembelajaran Matematika. Yogyakarta: Graha Ilmu.

Yovita, Bambang, \& Halini. (2013). Pengaruh Problem Based Learning Terhadap Kemampuan Komunikasi Matematis Siswa Pada Materi Himpunan Kelas VII. Jurnal Pendidikan Dan Pembelajaran, 2(10), 1-10. 